\title{
MICROCLIMATE OBSERVATION AT HERMANN'S TORTOISE (TESTUDO HERMANNI BOETTGERI) HABITAT IN THE “IRON GATES” NATURAL PARK. CASE STUDY: LOWER EȘELNIŢA WATERSHED (BANAT, ROMANIA)
}

\author{
Cristiana-Maria CIOCANEA *, \\ Athanasios-Alexandru GAVRILIDIS * and Vasile BAGRINOVSCHI *
}

* University of Bucharest, Centre for Environmental Research and Impact Studies, Nicolae Bălcescu Boulevard 1, Sector 1, Bucharest, Romania, RO-010041, cristianamaria.ciocanea@g.unibuc.ro, athanasiosalexandru.gavrilidis@g.unibuc.ro,vasilebagrinovschi@yahoo.com

DOI: $10.1515 /$ trser-2015-0032

KEYWORDS: microclimate, Eșelnița, “Iron Gates” Natural Park, Romania.

\section{ABSTRACT}

"Iron Gates" Natural Park is located in the South-Western part of Romania and is recognized for its great diversity of ecosystems, wide variety of species and emblematic landscapes. Due to its Mediterranean climatic influences and vegetation structure, the area is a suitable habitat for the existence and development of Testudo hermanni boettgeri.

Monitoring both, the evolution of the microclimatic features in the lower Eșelnița watershed and the species behaviour, represents a useful step in order to determine if the global climate change endangers the conservation management of the tortoise.

RESUMEN: Observaciones microclimáticas del habitat de la tortuga de Hermann (Testudo hermanni boettgeri) en el Parque Natural "Puertas de Hierro". Estudio de caso: la cuenca baja del Río Eșelnița (Rumania).

El Parque Natural "Puertas de Hierro", situado en el suroeste de Rumanía, es reconocido por albergar una gran diversidad de ecosistemas, especies y paisajes emblemáticos. Gracias a la influencia climática mediterránea, el área representa un hábitat adecuado para la especie Testudo hermanni boettgeri.

El monitoreo de los cambios microclimáticos en la cuenca baja del Río Eşelniţa y las observaciones del comportamiento de la especie, son indispensables para establecer si la conservación de la especie va a estar afectada por el cambio climático global.

REZUMAT: Observații microclimatice în habitatul țestoasei lui Hermann (Testudo hermanni boettgeri) din Parcul Natural „Porţile de Fier”. Studiu de caz: Bazinul inferior al râului Eșelnița (România).

Parcul Natural „Porţile de Fier”, localizat în partea de sud-vest a României, este recunoscut pentru diversitatea ecosistemelor, varietatea mare de specii şi peisajele emblematice. Datorită influențelor climatice mediteraneene și a vegetaţiei specifice, arealul reprezintă un habitat propice existenţei şi dezvoltării speciei Testudo hermanni boettgeri.

Monitorizarea evoluției caracteristicilor alături de observații privind comportamentul speciei, reprezintă un demers necesar pentru a stabili dacă, în contextul schimbărilor climatice, conservarea speciei poate fi periclitată în arealul bazinului inferior al râului Eșelnița. 


\section{INTRODUCTION}

Human society's adaptation to global climate change represents a major challenge of the 21st century (EEA, 2012). Biodiversity is one of the most vulnerable components facing the global climate change due to the habitat loss (Zisenis, 2010; Lavergne et al., 2010). Climate changes occurring at a global level are causing changes at a microclimatic level, affecting restricted habitats with high biodiversity (Fernández-Chacón et al., 2011). Thus, the areas exposed to the global climate changes are under a constant threat generated by the irreversible phenomenon that cannot be man handled. If the habitat fragmentation level, the overpopulation, the extent of the built-up or agricultural areas can be managed by sustainable management and policies, climate changes cannot be stopped on a long term because they are part of the cyclic process of Earth (IPCC, 2001). Therefore, the scientific community along with stakeholders and local actors have to acknowledge which are the required actions in order to slow down the rhythm of climate change. The reduction or loss of habitats due to climate change represents a direct threat to species with a narrow range of activity and a low velocity that can't cover long distances and are highly sensitive towards changes that occur in the environment (Popescu et al., 2013). The sensitiveness is generated by the fact that these species depend on other support species affected by climate changes.

Hermann's tortoise (Testudo hermanni boettgeri) represents a flagship species for the "Iron Gates" Natural Park (IGNP) and it is strictly protected due to the decreased number of individuals caused by illegal trade and habitat reduction (Rozylowicz and Dobre, 2010; Cucu et al., 2013). Testudo hermanni's biogeographic area is located along the northern shore of the Mediterranean Sea. There are three subspecies in this area: Testudo hermanni hermanni, in the north-east of Spain, Italian shore, Sicily and Sardinia islands, southern shore of France and Corsica Island; Testudo hermanni hercegovinensis on the eastern shore of the Adriatic Sea and Testudo hermanni boettgeri spreaded in the Balcanic Peninsula and south-western Romania (Fritz et al., 2006). The present study is addressed to the Testudo hermanni boettgeri from the IGNP.

This tortoise is a species that prefers habitats with a mosaic pattern, with different types of land use. It prefers areas with relatively restricted wide opened vegetation, surrounded by shrubs and forest selvage dominated by thermophile edge elements (Meek, 1985; Rozylowicz, 2008; Fernández-Chacón et al., 2011). These types of vegetal associations are the proper habitat for the tortoise which ensures the required elements for all its developmental stages. Changes occurring at a microclimatic level have a great impact over the habitat structures and we can add to that the usually anthropic threats. Testudo hermanni boettgeri has a high rate of survival among adult individuals, with longevity that exceeds 50 years and low range of movement (1-2 ha) (Bertolero et al., 2007; Couturier et al., 2014). The presence of Testudo hermanni boettgeri in the IGNP represents the northernmost area where the species was spotted the main explanation being the Mediterranean climate influence in this part of the country. Therefore it is of national importance to preserve the habitats and to reduce the threats towards Hermann's tortoise. 
As all reptiles, Hermann's tortoise behaviour is strongly influenced by the environmental conditions, mostly by the air temperature and humidity (Meek, 1988a; Popescu et al., 2013; Berardo et al., 2015). The optimum thermic range for Hermann's tortoise is situated between $25^{\circ} \mathrm{C}$ and $30^{\circ} \mathrm{C}$ (Huot-Daubremont et al., 1996). The minimum critical range is situated between $+1.5^{\circ} \mathrm{C}$ and $-2^{\circ} \mathrm{C}$, and the maximum critical range is situated between $40^{\circ} \mathrm{C}$ and $44^{\circ} \mathrm{C}$ (Cherchi, 1956; Huot-Daumbremont, 2002; Royzlowicz, 2008). Temperature has a decisive influence over the tortoise's metabolism, its diurnal and nocturnal activities, reproduction or hibernation period (Huot-Daubremont et al., 1996; Mazzoti et al., 2002; Hulin et al., 2009). Hermann's tortoise is a species with a small distribution area, restricted by climatic variables (Rozylowicz, 2008; Fernández-Chacón et al., 2011), which imposes natural barriers that are amplified by anthropogenic threats.

Being a poikilothermic species it does not have any internal metabolic mechanism for maintaining an optimum physiological body temperature (Meek, 1988a). Variation in air temperature determines the variation of the tortoise body temperature, thus during extreme climatic events their activity is ceased (Meek, 1988b; Huot-Daubremont et al., 1996). Hermann's tortoise has several behavioural features that help them survive during an episode of extreme cold or extreme heat such as soil or foliage burial and hiding under shrubs. Besides the behavioural features, Testudo hermanni boettgeri has some physiological features that help it pass through an episode of extreme temperatures such as becoming immovable while its biological functions are at a minimum stage, activities such as grazing being inhibited (Chelazzi and Calzolai, 1986; Meek, 1988b). This thermoregulatory behaviour makes it vulnerable in face of attacks from various predators during its inactivity period. Thus, the habitat expansion possibilities towards areas with an optimum climate are limited. In case of repeated extreme temperatures the number of the Hermann's tortoise individuals will constantly decrease, the most vulnerable individuals being the juveniles.

Air temperature shapes also the sexual cycle of the tortoise. The physiological processes linked to the reproductive cycle (spermiogenesis, gonadal cycle) are differently influenced by temperature, thus there is no perfect synchronization of these processes (Cheylan, 2001). Hermann's tortoise spermiogenesis start at a diurnal average temperature above $26^{\circ} \mathrm{C}$ and it stops at $21^{\circ} \mathrm{C}$ diurnal average temperature. The tortoise gender is determined by the incubation temperature (Eendebak, 2001). It has been ascertained that the tortoise sex ratio can be strongly imbalanced by uncharacteristic temperatures. Thus, at an incubation temperature around $26^{\circ} \mathrm{C}$ the hatched individuals would be males and at an incubation temperature around $32^{\circ} \mathrm{C}$, the hatched individuals would be females. The ideal temperature that determines a well-balanced sex ration and a low mortality of unhatched individuals is $28.5^{\circ} \mathrm{C}$ (Rozylowicz, 2008).

The study area is represented by the lower Eșelnița Watershed, located in southwestern part of Romania (Mehedinţi County) on the left bank of the Danube, as a part of IGNP (Fig. 1). The study area is characterized by a temperate climate with strong Mediterranean influences which determines specific vegetation structures with Mediterranean thermophile plant species. Thus, the study area represents a proper habitat for the Testudo hermanni boettgeri subspecies. 


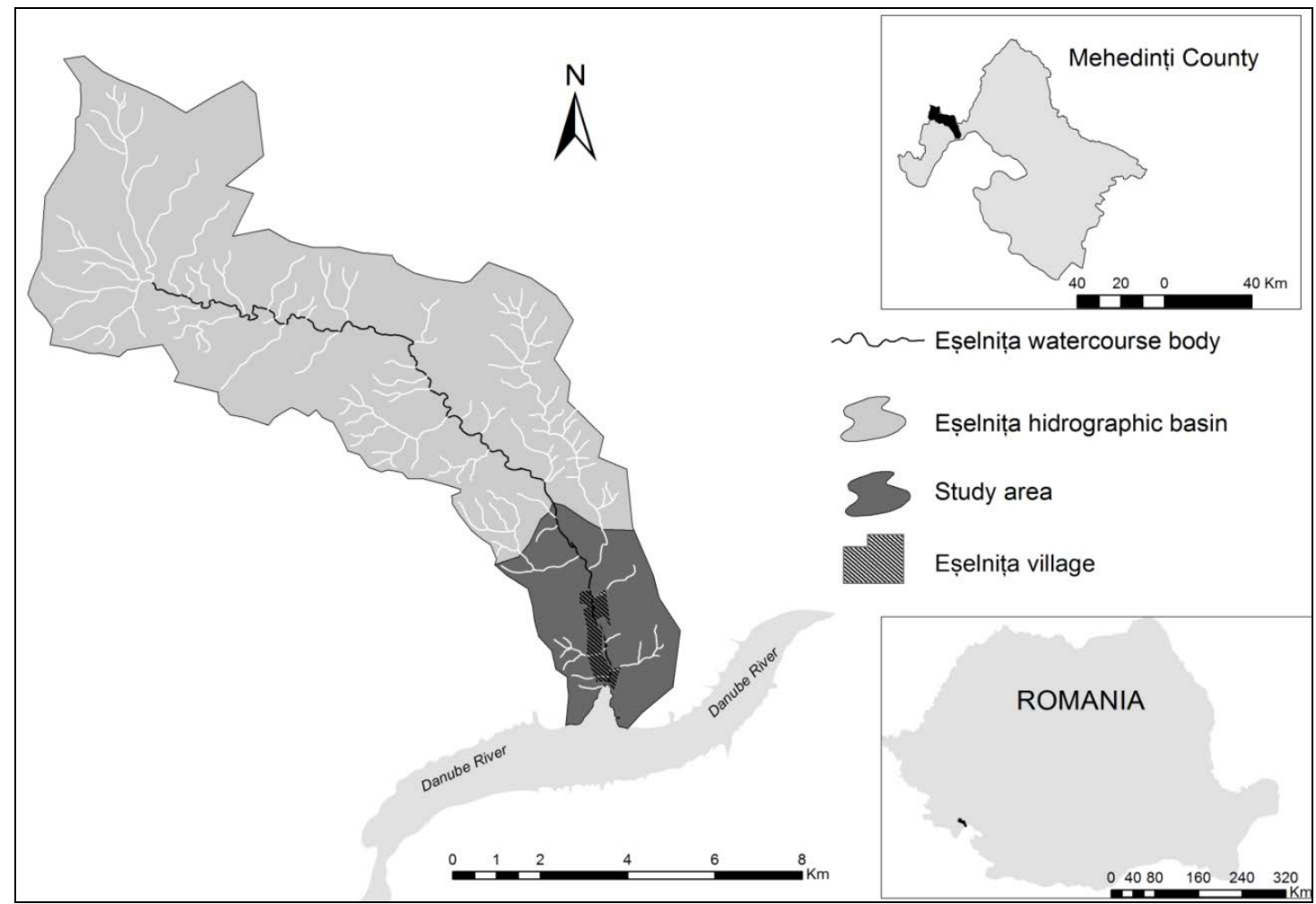

Figure 1: Study area and its position within Romania and Mehedinți County.

Due to circulation of the Mediterranean warm air masses, the temperature recorded in the mountains of the IGNP are higher than the average mountain temperatures. Near the Danube the local climate is similar with the Mediterranean climate; the multi-annual mean temperature recorded is $11^{\circ} \mathrm{C}$. The morphological features of the Danube River in the IGNP sector, determines an increase of temperature from west to east (Bazac and Moldoveanu, 1996; Pătroescu et al., 2005).

Monitoring the evolution of the microclimatic features in lower Eșelnița Watershed is a necessary step for many aspects. Being part of a protected natural area the current study may have an important role in improving the efficiency of the conservation measures, generating clear objectives to be included in the management plans or in future conservation policies. On the other hand, Hermann's tortoise behaviour correlated with the evolution of microclimatic features from our study area shows if in this particular case global climate changes generates positive or negative effects over its habitat.

The research question of this study is whether the evolution of the microclimatic features from our study area could endanger the conservation level for Testudo hermanni boettgeri. In order to answer the research question it was necessary to 1) evaluate the evolution of the microclimatic features in the past 10 years in comparison with the data recorded at three other meteorological stations within the IGNP and 2) to asses if these local microclimatic feature threatens to Hermann's tortoise presence in the area. The study is focused mainly on the temperature features because it induces important changes in the tortoise's habitat along with the soil temperature and air relative humidity. 


\section{METHODS}

We monitored and recorded the temperature and humidity parameters for the study area in the past eight years (2007-2014), at the location of the Centre for Habitats and Species Monitoring (University of Bucharest) located in Eșelnița (Mehedinți County). We used climatic data for comparisons between the lower Eșelnița Watershed and other areas from the "Iron Gates" Natural Park or its proximity from the meteorological stations Moldova Nouă, Berzasca and Drobeta Turnu Severin. We also compared the data from the analysed period with recordings extracted from the WorldClim database for the 1950-2000 timeframe.

We extracted information about tortoise behaviour from observations made between 2007-2013 in the reproduction and captivity-breeding habitat, which exists in the premises of the Centre for Habitats and Species Monitoring. The habitat was created using European funding in the LIFE Nature project RO/02/71/72 "Iron Gates" Natural Park - habitats conservation and management, implemented by the Centre for Environmental Research and Impact Studies (University of Bucharest).

We analysed data for the main climatic parameters (air and soil temperature, air relative humidity) using Microsoft Excel 2010, and derived a series of descriptive statistics from the data (multiannual, seasonal and hourly averages of air temperature, soil temperature and air relative humidity). We used the obtained data in establishing representative values for the habitat and behaviour of Hermann's tortoise in the "Iron Gates” Natural Park.

We used soil temperature in our analysis as a correlation parameter that would explain the direct relation between tortoises' presence and air parameters. The measurements were realised in the same habitat described above at depths of 0,5 and 10 centimetres, using the average temperature for the purpose of this present study.

\section{RESULTS}

Data analysis and processing revealed higher multiannual mean temperatures in our study area than in other areas within the IGNP (Fig. 2). The temperature in lower Eșelnița Watershed recorded $+2^{\circ} \mathrm{C}$ above the average temperature from the IGNP during the Testudo hermanni boettgeri (Fig. 3) activity seasons (Tab. 1).

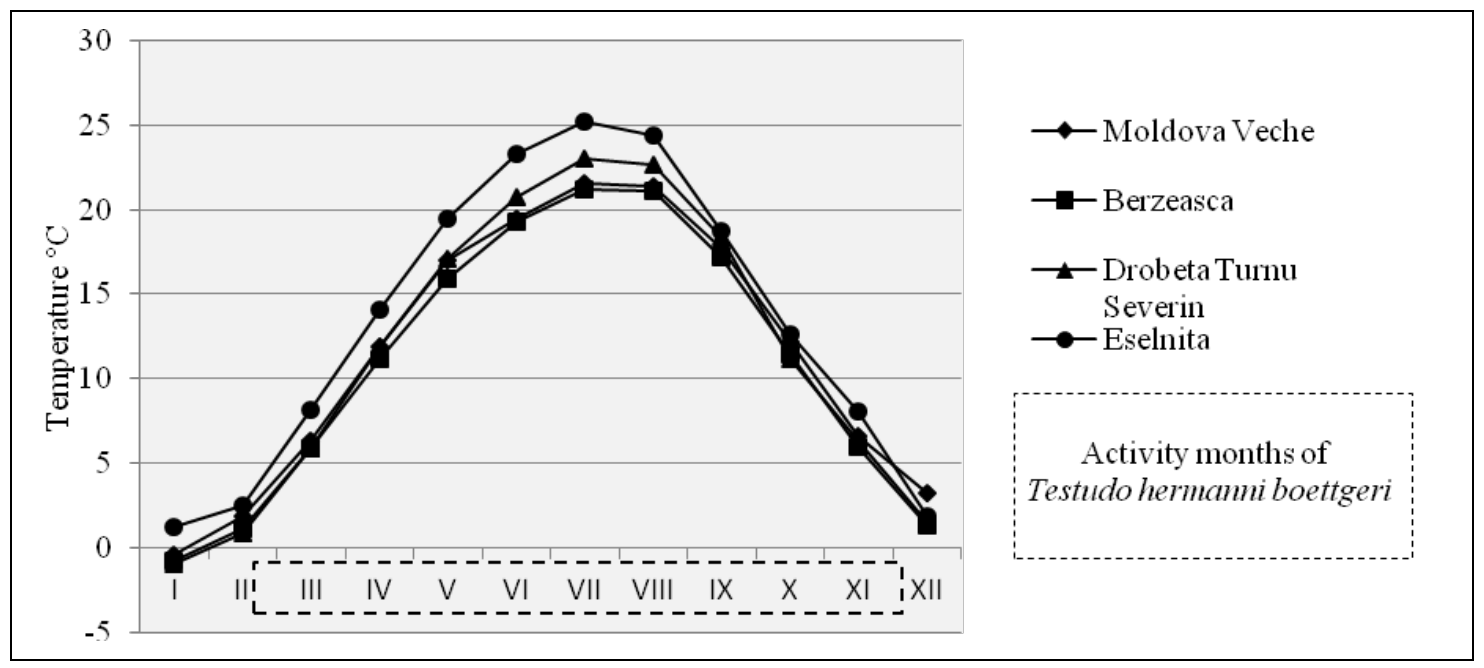

Figure 2: Multi-annual temperature recorded at

Eșelnița, Moldova Veche, Berzasca and Drobeta Turnu Severin. 
Table 1: Comparison between multiannual temperature values recorded at Eșelnița and the other three meteorological stations from the "Iron Gates" Natural Park.

\begin{tabular}{|c|c|c|c|c|}
\hline Month & Moldova Veche & Berzasca & Drobeta Turnu Severin & Eșelnița \\
\hline & ${ }^{\circ} \mathrm{C}$ & ${ }^{\circ} \mathrm{C}$ & ${ }^{\circ} \mathrm{C}$ & ${ }^{\circ} \mathrm{C}$ \\
\hline I & -0.4 & -0.8 & -1 & 1.25 \\
\hline II & 1.9 & 1.1 & 0.9 & 2.52 \\
\hline III & 6.3 & 5.9 & 5.9 & 8.18 \\
\hline IV & 11.9 & 11.2 & 11.9 & 14.11 \\
\hline V & 17 & 15.9 & 17.1 & 19.42 \\
\hline VI & 19.5 & 19.3 & 20.7 & 23.31 \\
\hline VII & 21.6 & 21.2 & 23 & 25.2 \\
\hline VIII & 21.4 & 21.1 & 22.7 & 24.38 \\
\hline IX & 17.7 & 17.2 & 18.4 & 18.72 \\
\hline X & 12.2 & 11.4 & 11.2 & 12.59 \\
\hline XI & 6.6 & 6 & 6.3 & 8.03 \\
\hline XII & 3.2 & 1.3 & 1.5 & 1.86 \\
\hline
\end{tabular}

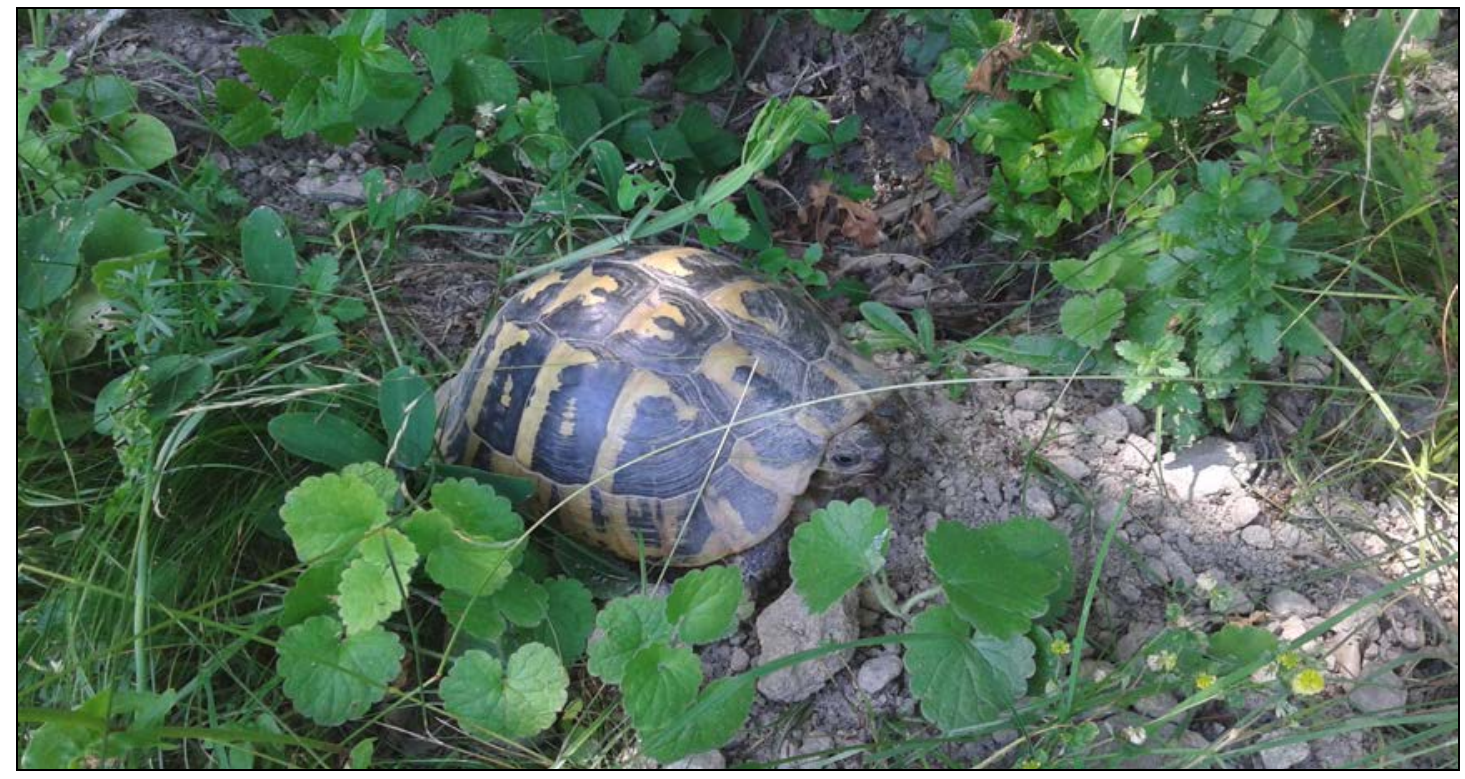

Figure 3: Testudo hermanni boettgeri in its natural habitat in Lower Eșelnița Watershed.

In order to determine if there has been important variation of the temperatures and relative humidity during the analysed period, a multiannual mean temperature and relative humidity values were calculated for three particular hours - 07:00, 13:00 and 19:00. Results revealed that the multiannual evolution had an oscillating pattern with an increasing trend for air and soil temperatures (Figs. 3 and 5) and a decreasing trend for the relative air humidity (Fig. 4). The current results can't lead to a major conclusion but they can emphasize the need for further analysis and monitoring. In order to conclude that the microclimatic parameters are changing in the lower Eșelnița Watershed an analysis of more than 50 years is required. 


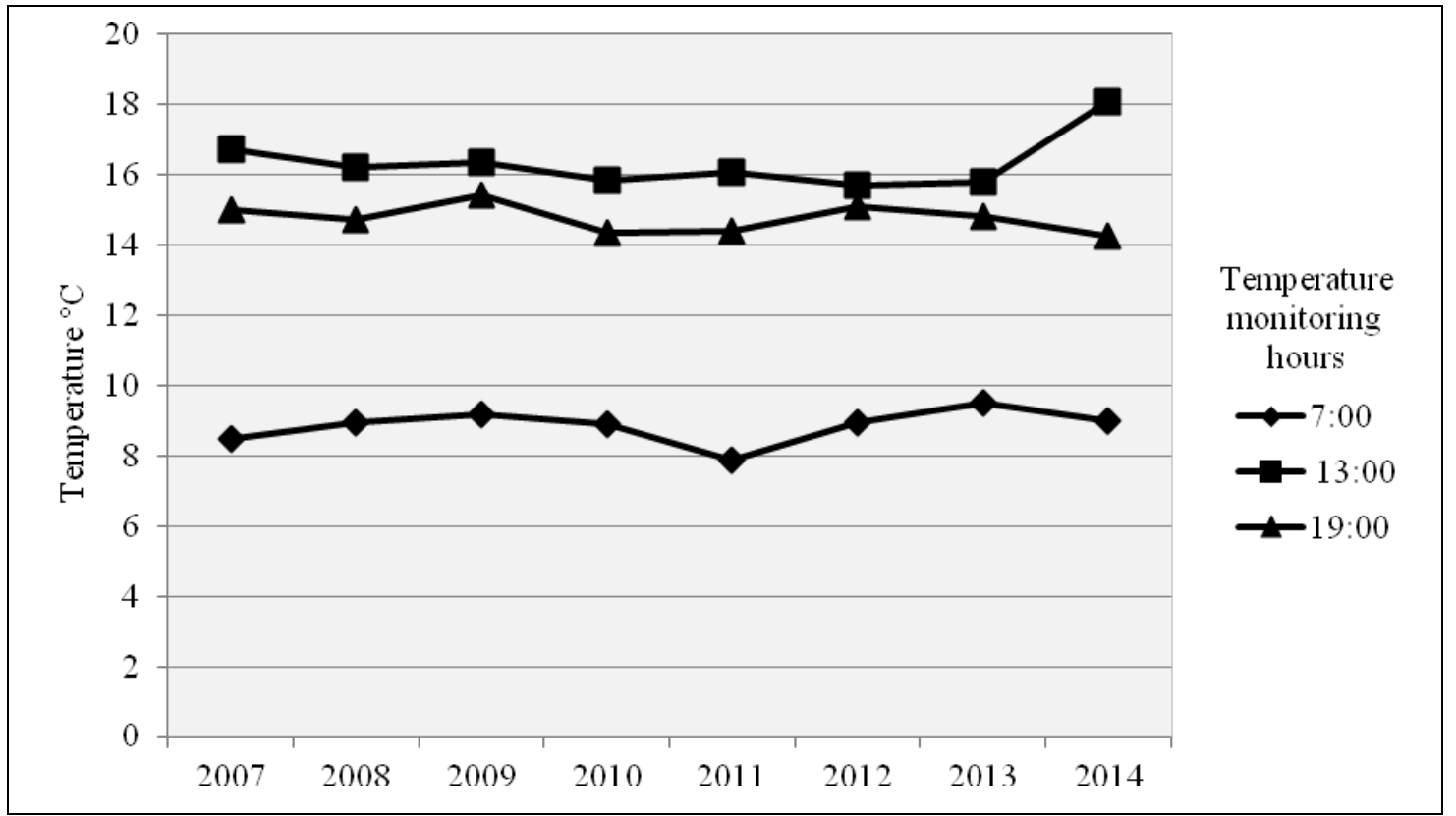

Figure 3: Air temperature evolution in lower Eșelnița Watershed (2007-2014).

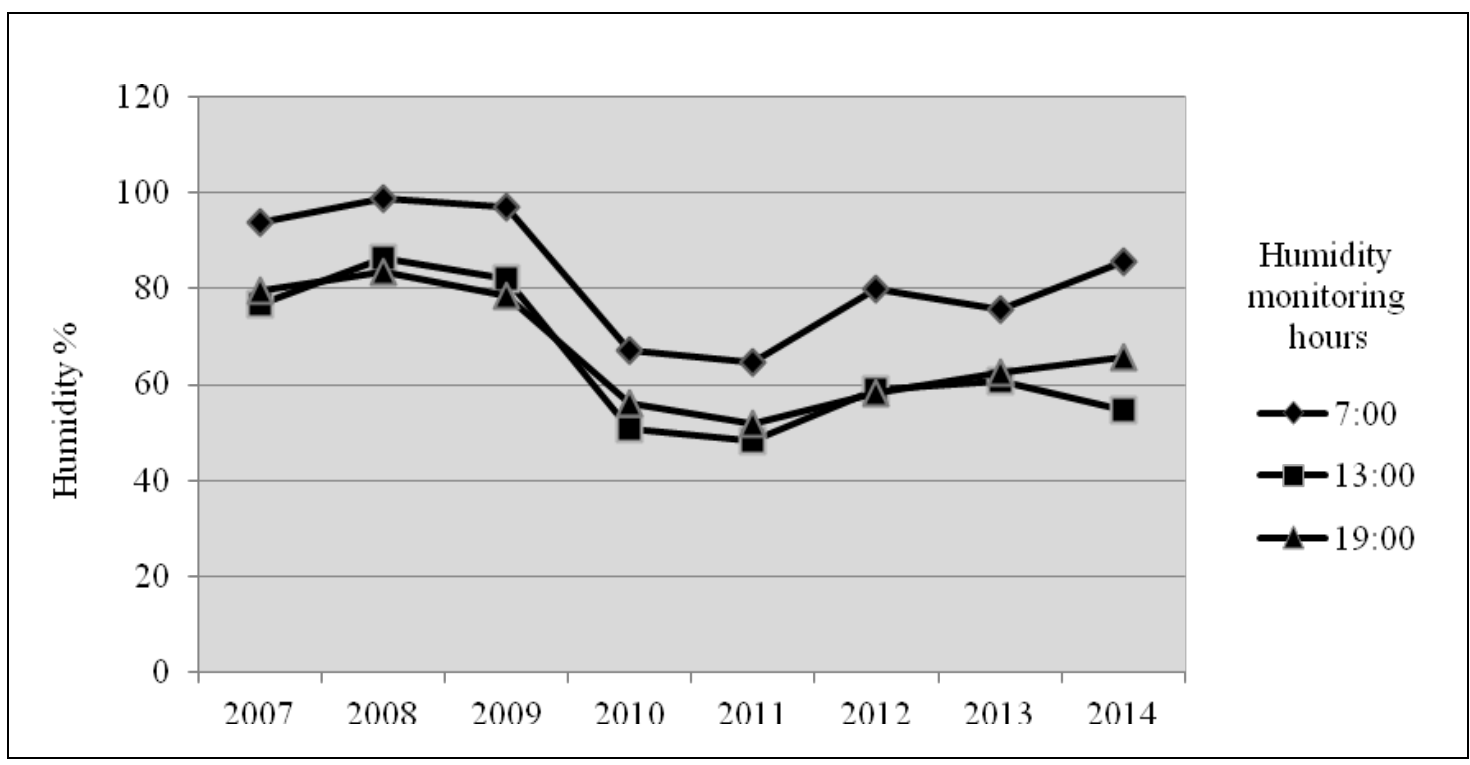

Figure 4: Air relative humidity evolution in lower Eșelnița Watershed (2007-2014). 


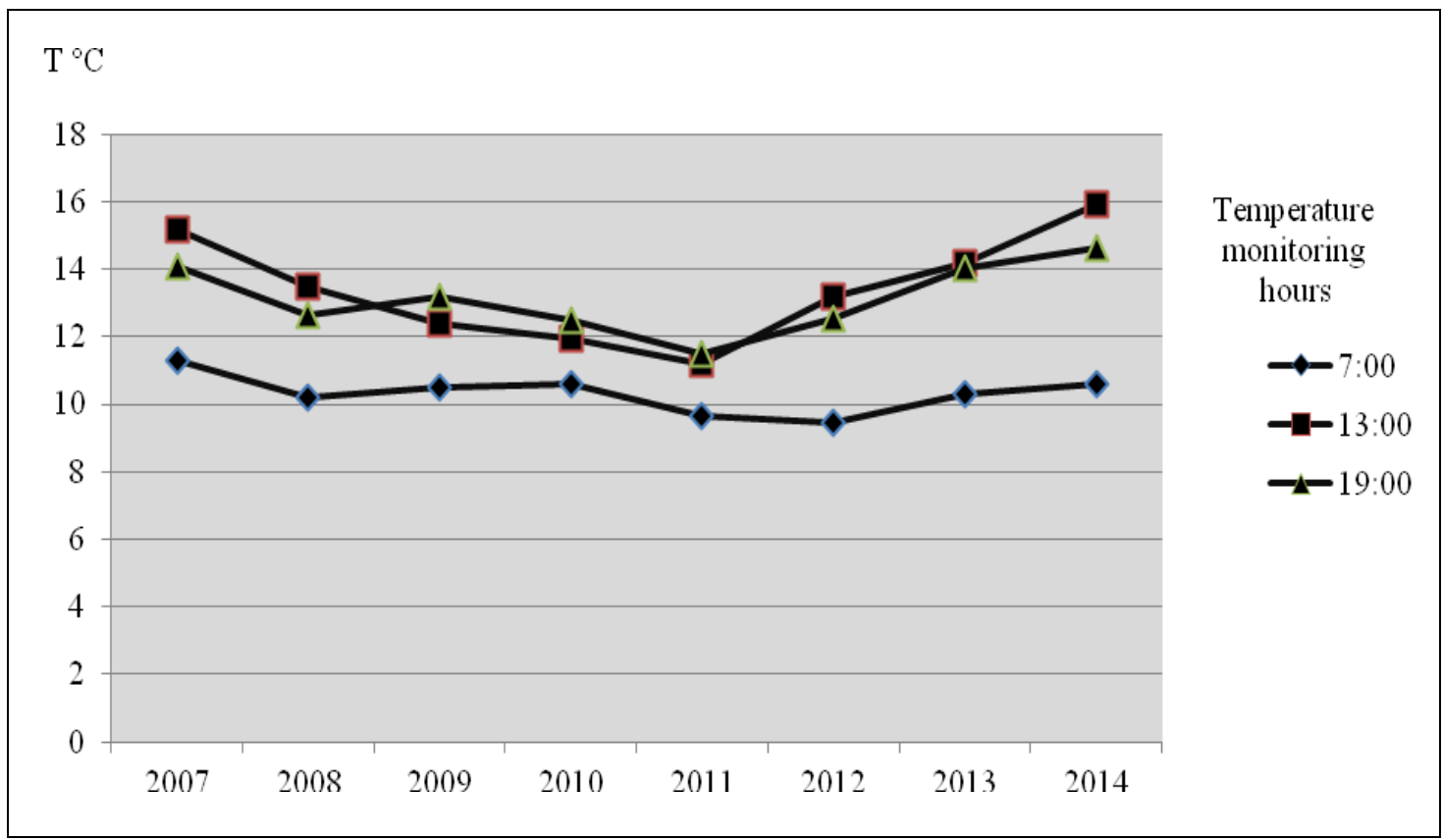

Figure 5: Soil temperature evolution

in lower Eșelnița Watershed (2007-2014).

Assessing the individual behaviour of Testudo hermanni boettgeri held in captivity at the Species and Habitat Monitoring Centre from Eșelnița, it was noted that during the monitoring period, the earliest date for the end of the hibernation season was recorded for the year 2008 on the 4th of March and the latest date for the activity season was recorded for 2007 and 2010 on the 11th of November (Fig. 6). It was also recorded that the year with the longest activity season for the individuals of Testudo hermanni boettgeri was in 2007 (Fig. 7), starting on the 10th of March and ending on the 11th of November.

In figure 8 , the oscillation of temperatures for each month of the year is emphasized using the multiannual mean values processed using the available data. According to the Hermann's tortoise activity month mentioned earlier, the longest period of activity for a tortoise starts from the 3rd month (March) and ends in the 11th month (November). As it is emphasized in the graph chart the month with the widest interquartile range is November fact that can explain why for two years the hibernation season started so late, due to high temperature values. Also the other two autumn months (September and October) have a wide interquartile range which suggests that the temperature values oscillate a lot in autumn influencing the behaviour pattern of the tortoise. Spring and summer seasons, which represent the period when Testudo hermanni boettgeri reaches its peak activity season, recorded more stable temperatures values representing a positive fact for the tortoise habitat. 


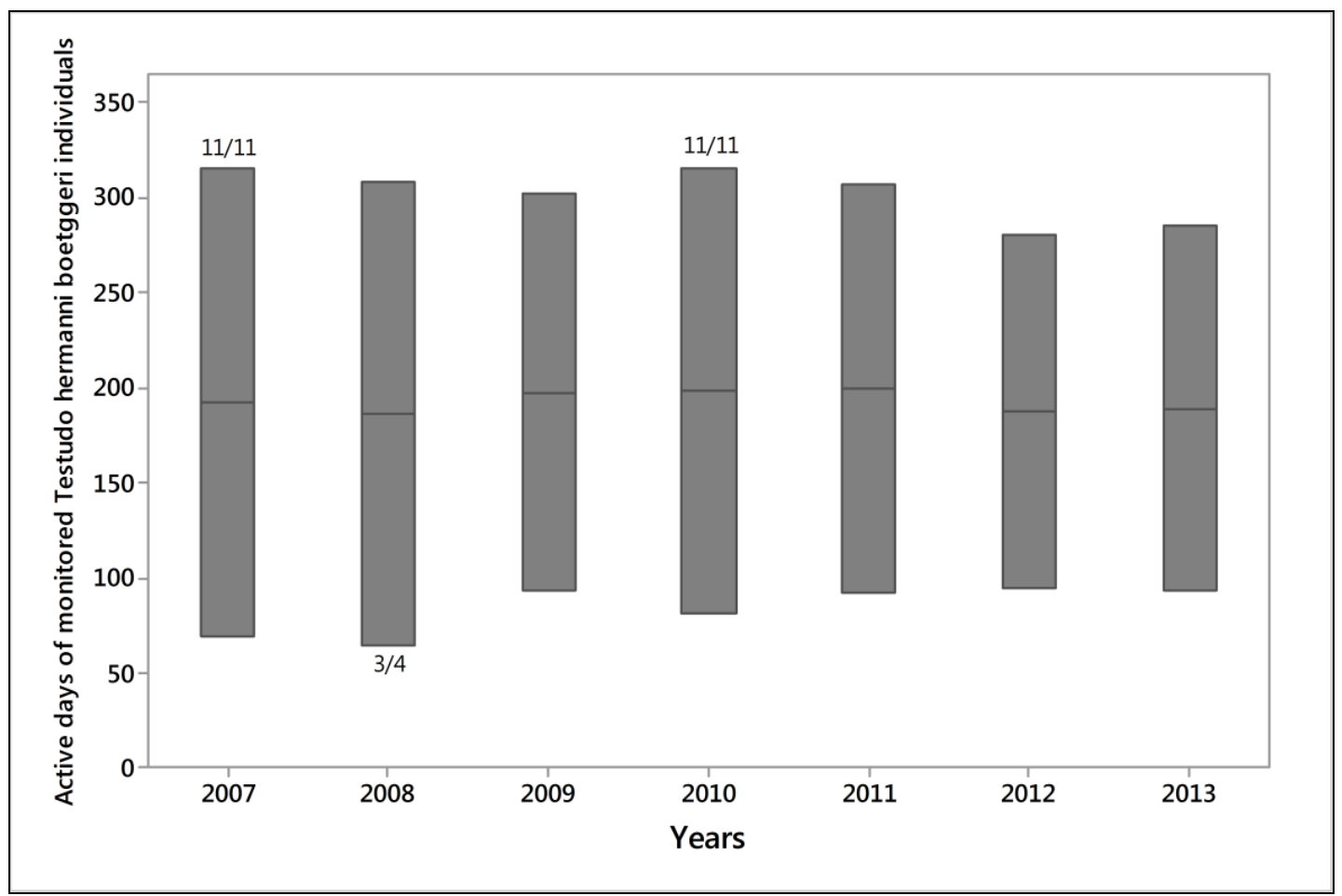

Figure 6: The time period within a year that Testudo hermanni boettgeri individuals were active in the Species and Habitat Monitoring Centre - Eșelnița.

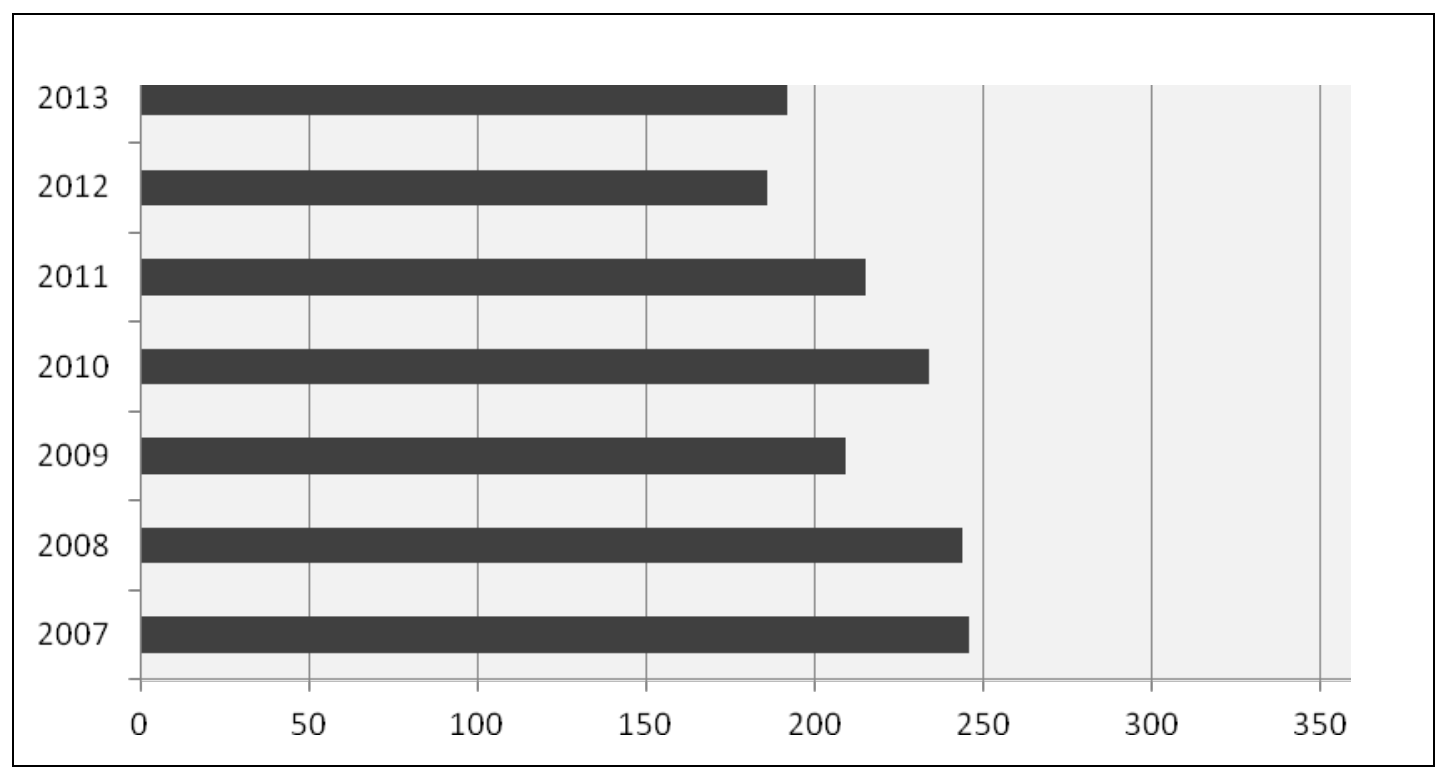

Figure 7: Number of effective days that Testudo hermanni boettgeri individuals were active in the Species and Habitat Monitoring Centre - Eșelnița. 


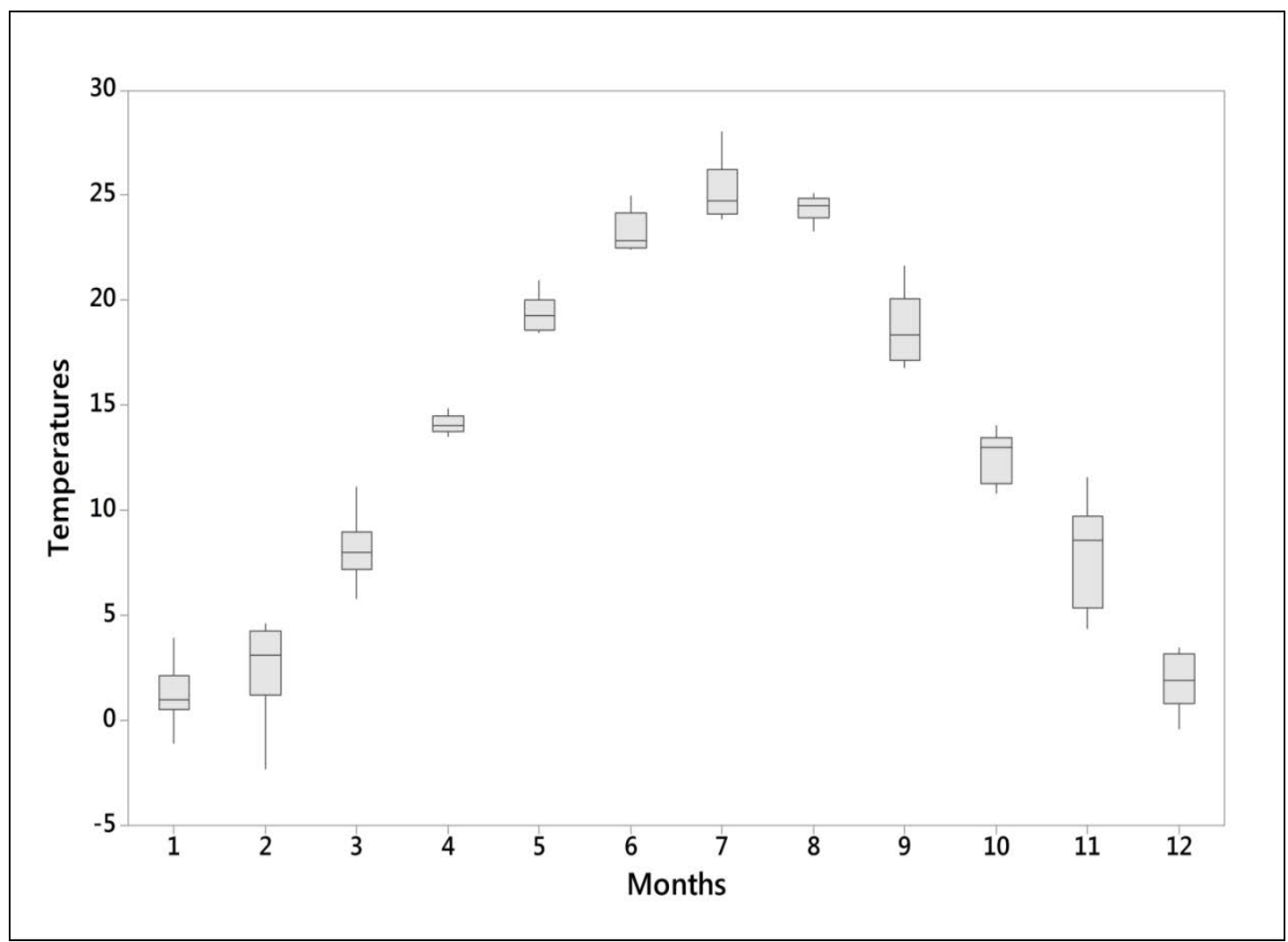

Figure 8: Multiannual mean temperature values for each month, the absolute oscillating range values and the interquartile range values recorded in the lower Eșelnița Watershed.

\section{DISCUSSION}

The annual life cycle for Hermann's tortoise can be divided into the sleep hibernation period (November - March/April) and the active period (March/April November), as confirmed by the data recorded at the Centre for Habitats and Species Monitoring, Eşelniţa. The sleep - hibernation period can be interrupted when periods of extremely high temperature are registered (Huot-Daumbremont, 2002).

The annual and diurnal life cycle of the tortoise is determined almost entirely by temperature. Being a poikilothermic species, the tortoise lacks internal metabolic mechanisms that would help it maintain an optimal body temperature when air temperature is higher or lower than the optimum. Fluctuations in air temperature determine variations of the behaviour and their adjustments to the environment (Fry, 1967). For Hermann's tortoise, numerous studies exist on the topic of thermoregulation mechanisms, in France, Greece, Italy and former Yugoslavia (Meek, 1988b; Huot-Daumbremont, 1997; Huot-Daumbremont, 2002; Mazzoti et al., 2002). Meek, 1987 observed that during summers with sunny days, body temperature for tortoises tends to be higher than air and soil temperature. At the maximum temperature of air and soil, body temperature is always lower. We therefore observed that Testudo hermanni boettgeri has a higher thermoregulation capacity in relation with air and soil temperatures. 
Results of the present study do not confirm the hypothesis that temperature oscillations are high enough in the lower Eșelnița Watershed so that they would endanger the adaptability of Hermann's tortoise. Rozylowicz and Dobre (2010) presented the average multiannual temperature in the area of Testudo hermanni boettgeri from south-western Romania to be $+10.28^{\circ} \mathrm{C}$, but climatic data from the Centre for Habitats and Species Monitoring, Eșelnița, revealed that the multiannual temperature is $+13.30^{\circ} \mathrm{C}$. Therefore, the lower Eșelnița Watershed represents an area with temperatures higher than the average of habitats occupied by Testudo hermanni boettgeri, as temperatures have increased between 2010 and 2013.

Centre for captivity breeding of Hermann's tortoise (the present Centre for Habitats and Species Monitoring) organised between 2005 and 2006 a radio-telemetry survey of tortoises in the Eşelniţa-Mala interfluve (Pătroescu et al., 2005). The conclusion of the study was that the relation between the home-range of Hermann's tortoise, behaviour, movements and environmental factors is highly influenced by temperatures (Rozylowicz, 2008).

A potential element of risk generated by higher temperatures in the lower Eșelnița Watershed is related to the appearance of vegetation fires. The vulnerability of the tortoise to fires is increased by the fact that many of the habitats used by Testudo hermanni boettgeri are pastures maintained and exploited by local population.

\section{CONCLUSIONS}

The study area of the lower Eșelnița Basin represents a stable region regarding climatic parameters, therefore an excellent habitat for populations of Testudo hermanni boettgeri. Higher temperature values in the study area compared to those recorded at the meteorological stations of Moldova Veche, Berzasca and Drobeta Turnu Severin is an indicator of a warmer climate. The reduced amplitude of oscillations in the annual values for the period of observations (a maximum of $2^{\circ} \mathrm{C}$ for air temperature, $26.87 \%$ for relative humidity and $3.48^{\circ} \mathrm{C}$ for soil temperature) is an element favourable for the different evolution phases of Testudo hermanni boettgeri individuals. In order to elaborate in-depth conclusions on the oscillations of climatic parameters in the lower Eșelnița Basin the monitoring period should be of 50 years.

\section{REFERENCES}

1. Bazac G. and Moldoveanu M., 1996 - Unele caracteristici ale influenţei mediteraneene asupra climei din sud-vestul României, Terra, XXVIII, 50-54. (in Romanian)

2. Berardo F., Carranza M. L., Frate F., Stanisci A. and Loy A., 2015 - Seasonal habitat preference by the flagship species Testudo hermanni, Comptes rendus biologies, 338, 5, 343-350.

3. Bertolero A., Oro D. and Besnard A., 2007 - Assessing the efficacy of reintroduction programmes by modelling adult survival, Animal Conservation, 10, 3, 360-368.

4. Chelazzi G. and Calzolai R., 1986 - Thermal benefits from familiarity with the environment in a reptile, Oecologia, 68, 4, 557-558.

5. Cherchi M. A., 1956 - Termoreglazione in Testudo hermanni Gmelin, Bolletino dei Musei e Degli Istituti Biologici dell'Universita di Genova, 26, 5-46. (in Italian)

6. Cheylan M., 2001 - Testudo hermanni Gmelin, 1789 - Griechische Landschildkrote, in Fritz U., (ed.), Handbuch der Reptilien und Amphibien Europas, Aula Verlag, 179-289. (in German)

7. Couturier T., Besnard A., Bertolero A., Bosc V., Astruc G. and Cheylan M., 2014 - The abundance of Hermann's tortoise in France and Spain, Biological Conservation, 170, 177-187.

8. Cucu L. A., Niculae M. I. and Pătroescu M., 2013 - Hierarchical analysis of the threats for Species of Community Interest in the "Iron Gates" Natural Park, Romania, Forum geografic, Studii și cercetări de geografie și protecția mediului, 12, 1, 52-58. 
9. EEA, 2012 - Climate change, impacts and vulnerability in Europe 2012, Copenhagen European Environment Agency, 213-237.

10. Eendebak B. T., 2001 - Incubation period and sex ratio of Testudo hermanni boettgeri, International Congress on Testudo Genus, Hyères, 227-331.

11. Fernández-Chacón A., Bertolero A., Amengual A., Tavecchia G., Homar V. and Oro D., 2011 Spatial heterogeneity in the effects of climate change on the population dynamics of a Mediterranean tortoise, Global Change Biology, 17, 10, 3075-3088.

12. Fritz U., Auer M., Bertolero A., Cheylan M., Fattizzo T., Hundsdorfer A. K., Sampayo M. M., Pretus J. L., Široky P. and Wink M., 2006 - A rangewide phylogeography of Hermann’s tortoise, Testudo hermanni: implications for taxonomy, Zoologica Scripta, 35, 5, 531-543.

13. Fry F. E. J., 1967 - Responses of vertebrate poikilotherms, Academic Press, London, 375-409.

14. Hulin V., Delmas V., Girondot M., Godfrey M. H. and Guillon J. M. 2009 - Temperaturedependent sex determination and global change, Oecologia, 160, 3, 493-506.

15. Huot-Daumbremont C., 1996 - Contribution a l'etude ecophysiologique de different aspects du cycle de la tortue d’Hermann (Testudo hermanni hermanni) dans le massif des Maures (Variable), Thèse de Doctorat, Université de Tours-François Rabelais, 35-152. (in French)

16. Huot-Daubremont C., Grenot C. and Bradshaw D., 1996 - Temperature regulation in the tortoise Testudo hermanni, studied with indwelling probes, Amphibia-Reptilia, 17, 2, 91-102.

17. Huot-Daumbremont C., 1997 - Rythme d'activite de la tortue d'Hermann, Bolletino dei Musei e Degli Istituti Biologici dell'Universita di Genova, 26, 5-46. (in French)

18. Huot-Daumbremont C., 2002 - Etude de la thermoregulation de la tortue d'Hermann (Testudo hermanni hermanni) en semi-liberte dans le massif des Maures (Variable), Revue d'Ecologie (Terre Vie), 52, 331-334. (in French), 52, 331-334. (in French)

19. IPCC, 2001 - The Scientific Basis. Contribution of Working Group I to the Third Assessment Report of the Intergovernmental Panel on Climate Change, Houghton J. T., Ding Y., Griggs D. J., Noguer M., van der Linden P. J., Dai X., Maskell K. and Johnson C. A. (eds), Cambridge University Press, Cambridge, United Kingdom and New York, NY, USA, 881.

20. Lavergne S., Mouquet N., Thuiller W. and Ronce O., 2010 - Biodiversity and climate change: integrating evolutionary and ecological responses of species and communities, Annual review of ecology, evolution and systematics, 41, 321-350.

21. Mazzoti S., Pisapia A. and Fasola M., 2002 - Activity and home range of Testudo hermanni in Northern Italy, Amphibia-Reptilia, 23, 305-312.

22. Meek R., 1985 - Thermoregulatory behaviour in a population of Hermann tortoise (Testudo hermanni) in southern Yugoslavia, British Journal of Herpetology, 6, 387-39.

23. Meek R., 1988a - The comparative population ecology of Hermann tortoise, Testudo hermanni, in Croatia and Montenegro, Yugoslavia, Herpethological Journal, 404-414.

24. Meek R., 1988b - The thermal ecology of Hermann's tortoise (Testudo hermanni) in summer and autumn in Yugoslavia, Journal of Zoology, London, 215, 99-111.

25. Pătroescu M., Rozylowicz L. and Dobre M., 2005 - Activitatea şi teritoriul ţestoasei lui Hermann din Parcul Natural Porţile de Fier, raport de cercetare, 4-19. (in Romanian)

26. Popescu V. D., Rozylowicz L., Cogălniceanu D., Niculae M. I. and Cucu L. A, 2013 - Moving into protected areas? PLOS ONE, 9, 1, 1-14.

27. Primack R. B., Pătroescu M., Rozylowicz L. and Iojă I. C., 2008 - Fundamentele conservării diversităţii biologice, Edit. AGIR, Bucureşti, 196-237. (in Romanian)

28. Rozylowicz L., 2008 - Metode de analiză a distribuţiei areal-geografice a ţestoasei lui Hermann (Testudo hermanni Gmelin, 1789) în România, 16-115. (in Romanian)

29. Rozylowicz L. and Dobre M., 2010 - Assessing the threatened status of Testudo hermanni boettgeri Mojsisovics, 1889, North-Western Journal of Zoology, 6, 2, 190-202. 